\title{
COVID-19 AND INFORMAL LABOUR IN CONSTRUCTION: A NARRATIVE ANALYSIS OF WEBINAR DISCUSSIONS
}

\author{
Chandana Jayalath ${ }^{1}$ and K.K.G.P. Somarathna ${ }^{2}$
}

\begin{abstract}
Many countries after a remarkable spike in COVID-19 cases, opted to lockdown and quarantine curfew that restricted the movement of people. Construction is one of the main sectors experiencing a clear impact due to COVID-19. As a significant growth driver of the economy, the domestic construction industry employs nearly one million of the population directly in various trades. Unfortunately, almost every project has been severely hampered. It is, therefore, prudent to address the impact of the pandemic on construction labour at the outset and end of the crisis to prepare for any future challenges or opportunities that it may undergo. This study aims to investigate the effect of COVID-19 on the construction industry's survival and possible measures to be taken in both the short and the long run. This paper summarizes using a narrative analysis of the key takeaways of 15 webinar discussions on the COVID-19 impact and outlook of the construction sector in Sri Lanka. The impacts and fallouts have been addressed by key industry personnel. The study found the most prominent impacts of COVID-19 are the suspension of projects, labour impact, and job loss, time overrun, cost overrun, and delay in payments. The findings of this study shed light on the consequences of the sudden occurrence of a pandemic and raise awareness of the most critical impacts which cannot be overlooked. The findings also help project stakeholders prepare for any future worstcase scenarios.
\end{abstract}

Keywords: Construction labour; COVID-19; Informal labour; Labour crisis; Pandemic.

\section{INTRODUCTION}

The outbreak of COVID-19 has enormously affected almost every participant in the construction industry, be them contractor, consultant or client. Since the supply chains have been disrupted, there is a potential of cost over run (Bailey et al. 2020; Robertson, 2020). Due to the recent travel restrictions, managing workforce is a challenging task. Increased health, safety and environmental issues led for higher expenses to the contractor (Turrini, 2020). Labour shortages, governmental restrictions including ban on gatherings and the contractor's personnel, or suppliers are either ill or under quarantine, are the situations causing critical delay and inability to meet the initial deadlines (Shorter and Nairac, 2020; European International Contractors, 2020). The demand for middle income apartments are likely to be offset by the current and expected economic downturn (PWC, 2020). During the COVID-19 pandemic, the situation drastically deteriorated first by the

\footnotetext{
${ }^{1}$ Department of Quantity Surveying, University of Vocational Technology, Sri Lanka, jayalathchandana@gmail.com

${ }^{2}$ University College of Batangala, Sri Lanka, kkgpsomarathna123@gmail.com
} 
shortage of material supply. Following the spread of the virus, many countries started implementing several measures to reduce the movement of people, and that has mainly affected the progress of construction work because it requires on-site work. Globally, millions of employees lost their jobs. In the construction industry, almost every tradesman lost their jobs and most of the small enterprises are not able to pay salaries during lockdowns. The literature about the pandemic is still scarce, especially in the construction industry sector. Hence, it is crucial to investigate the impact of the pandemic in the construction industry with reference to the impact on labour. This research depends largely on the opinions expressed by the key industry personnel via webinar discussions recently taken place in electronic media.

\section{LITERATURE SURVEY}

COVID-19 has been spreading drastically all over the world and is considered by the World Health Organization (WHO) as a pandemic (WHO, 2020). It has had far-reaching severe consequences. All the business activities have been shut down except for a few vital projects which are necessary to support the health system and safety of the people. Relatively, it has limited the business operations and companies have shifted to WorkFrom-Home (WFH) concept. However, in the construction industry, all the workers inevitably need to nearly work on-site either to perform activities or to monitor whether the work is done correctly (Financial Times, 2020). This is basically how the construction industry is different from other industries. Hence, it is crucial to appreciate how the construction industry addresses this unforeseen situation. Several studies have attempted to investigate the impact of COVID-19 on the economy and industrial sectors. A study by Fernandes (2020) addressed the economic impact of the pandemic outbreak on the economy of 30 countries and found that the gross domestic product (GDP) is likely to be hit by $3-6 \%$ or might fall by $15 \%$ in some countries.

The study revealed that the service-oriented economy is negatively impacted, and jobs are at risk and the countries that depend on foreign trade are likely to be affected the most in their GDP. Another study by Ayittey et al. (2020) shows that commerce, tourism, and trade are the most impacted sectors. Nicola et al. (2020) reported that the restrictions implied by the authorities had reduced mobility causing many industries to shut down the business operations. Ivanov (2020) studied the effect of the outbreak on the supply chain and found that almost every economic sector has been impacted negatively and it may take a longer time to recover. Harari (2020) also expressed that the COVID-19 pandemic is the biggest crisis of the generation, and it may take years to recover and action must be taken decisively to subsidize and plan new strategies to avoid the travail of humankind. Chalam (2020) found that the Indian real estate sector has been severely affected and declination has been considerably recorded. Helm (2020) also pointed out that the total lockdown caused by COVID-19 has severely curtailed economic activities. The construction industry with no exception has been severely affected by the COVID-19 pandemic.

Since the supply chains have been disrupted, it has been difficult to complete on time and there is a potential for cost overrun (Bailey, 2020; Robertson, 2020). Due to the recent travel restrictions and uncertainty around travel locally and globally, managing the workforce is a challenging task. Increased health, safety, and environmental issues lead to higher expenses for the contractor (Turrini, 2020). Labour shortages, governmental restrictions including a ban on gatherings, and the contractor's personnel or suppliers 
being ill or in quarantine, are the situations causing critical delay and inability to meet the project deadlines (Shorter, 2020; Osha, 2020). Delays in the completion of projects are partly due to the interruptions in the supply chain as voluminous raw materials are manufactured in China. Negative cash-flows, delays in the supply chain, and low investor confidence create a more problematic situation within the industry (William, 2020; European International Contractors, 2020).

As European International Contractors stated, the uptake of cross-border projects will require a higher- administrative burden as quarantine periods across the world vary in length. COVID-19 affects key cost components of construction projects (material and labour), and these challenges to on-going project delivery, companies' liquidity, and whole business models (Jayalath, 2020). Further, sub-contractors are unable to perform. Equipment rental companies are starting to face problems with equipment left on inoperative sites. The bankruptcy of smaller companies, contractors, subcontractors, and design professionals are frequent (European International Contractors, 2020). Disputes with main-contractors and sub-contractors, back-to-back force majeure claims under concession agreements to avoid liquidated damages are some of the complexities that arise (European International Contractors, 2020). As mentioned, force majeure clauses often list specific events such as earthquakes, earth slips, Tsunami, etc. Many such clauses will include in the list under Acts of God, which would not, however, seem to describe or encompass a global pandemic such as COVID-19 (Jayalath, 2020). Meanwhile, the liquidity crisis of companies with a high level of debt and low cash reserves, insolvency issues will linger the stakeholders to more disappointment (Deloitte, 2020). A significant increase in claims for delays or increased costs is because of the COVID-19 outbreak (Jayalath, 2020).

The Sri Lankan experience is not that far from global observations. The lockdown and curfews have restricted the distribution and retail of cement and dry mortar goods across the island (Economy next, 2020). The handover dates were postponed. Hence, suppliers were in a dilemma as the operating costs are increasing through, increases in, raw material costs, logistics, and expenditure related to special hygienic facilities (Economy next, 2020). The guidelines of Epidemiology Unit - Ministry of Health - Sri Lanka, stated that contractors need to supply all the hand hygiene facilities, facial masks, and other relevant personal protective equipment (PPEs) at the workplace, which may cause an additional cost. In Sri Lanka, several high-rise building projects have slowed down owing to the delay in the procurement of materials from China and the curfew. Lockdowns in China also adversely affected the industry as Chinese contractors undertake many construction projects in Sri Lanka (PWC, 2020). Thus, large-scale public sector construction activities may be suspended temporarily (Colombo Page, 2020). As such, the Sri Lankan construction supply chain was massively impacted due to the lockdown of China.

\section{RESEARCH AIM AND OBJECTIVES}

The aim of this research is to inspire dialogue among the decision-makers around the issue of informal labour in the construction industry during the COVID-19 pandemic. The objectives are to harness the outcome of a series of webinar discussions that took place within the period of March 2020 to April 2020 from both retrospective and prospective practical analysis, reveal the challenges that are currently being faced by industry personnel and recommend actions for implementation. More specifically, the discussion will consider not only the challenges in terms of labour dynamics induced by 
the COVID-19 crisis, but also the opportunities the pandemic presents for these pertinent processes in the construction industry.

\section{RESEARCH METHODOLOGY}

A literature review was carried out using research papers and technical articles that appeared in open free access sources on the internet since January 2020 where the spread of COVID-19 became evident and declared a pandemic by the WHO. A thorough review of webinar outcomes that are in the public domain was undertaken to identify various issues at the contracting firm level. Webinars are a frequent online qualitative research approach. For example, webinar delivery platforms as a tool for collection of qualitative data are popular because of ease of use and cost-effectiveness (Mandy et al., 2019). Wen Ni Tiong et al. (2020) confirmed that data derived from webinar sessions are consistent with the quantitative results, and the potential of its uses as a new research tool to collect quality observation data. Out of a series of COVID-19 webinar recordings freely available in the internet, the selection of webinar recordings has been based upon the topic of the webinar discussion and stake of the professional organization has in disseminating construction labour data. 19 webinar sessions that address some of the key issues arising from the pandemic, were purposely selected. These include the lessons to be learned and sharing best practices to benefit construction and infrastructure firms over the challenging months ahead. All sessions were free to attend and were hosted on the Zoom webinar platform the profile of which is given in Table 1.

Table 1: Profile of the webinar discussions

\begin{tabular}{|c|c|c|}
\hline Webinar & Organizer and Date & Theme of Focus Group Discussion \\
\hline 1 & FIDIC, April 8, 2020 & $\begin{array}{l}\text { COVID-19: and its impact on contracts, supply and } \\
\text { labour, activities on site and dealing with force majeure }\end{array}$ \\
\hline 2 & $\begin{array}{l}\text { RICS Sri Lanka, April } \\
27,2020\end{array}$ & $\begin{array}{l}\text { COVID-19 and the impact of real estate market in Sri } \\
\text { Lanka; free webinar session ii. focused on vertical } \\
\text { living, urban resilience, and re-emergence of the } \\
\text { construction industry }\end{array}$ \\
\hline 3 & RICS UK, May 1, 2020 & $\begin{array}{l}\text { Ensuring construction site safety and project continuity } \\
\text { during COVID-19 }\end{array}$ \\
\hline 4 & FIDIC, May 5, 2020 & $\begin{array}{l}\text { COVID-19: how lockdown is enabling more digital and } \\
\text { remote working }\end{array}$ \\
\hline 5 & FIDIC, May 7, 2020 & $\begin{array}{l}\text { COVID-19: managing employment relationships, } \\
\text { employees and health \& safety requirements }\end{array}$ \\
\hline 6 & BASL, May 10, 2020 & $\begin{array}{l}\text { Impact of COVID-19 in the sphere of labour law and } \\
\text { industrial relations in Sri Lanka }\end{array}$ \\
\hline 7 & FIDIC, June 3, 2020 & $\begin{array}{l}\text { Coming out of COVID-19: What will the 'new normal' } \\
\text { look like and how will we get there? }\end{array}$ \\
\hline 8 & IESL, July 7, 2020 & $\begin{array}{l}\text { The impact of COVID-19 on construction and } \\
\text { infrastructure development: path to recovery and } \\
\text { progress }\end{array}$ \\
\hline 9 & AIQS, August 22, 2020 & $\begin{array}{l}\text { Post COVID-19 construction operations and } \\
\text { employment management strategies for the } \\
\text { construction industry in Sri Lanka and an overview of } \\
\text { the middle east }\end{array}$ \\
\hline
\end{tabular}




\begin{tabular}{|c|c|c|}
\hline Webinar & Organizer and Date & Theme of Focus Group Discussion \\
\hline 10 & $\begin{array}{l}\text { PAQS, August 27, } \\
2020\end{array}$ & Pandemic claims and resolutions for quantity surveyors \\
\hline 11 & $\begin{array}{l}\text { PAQS, September 23, } \\
2020\end{array}$ & $\begin{array}{l}\text { Surviving post covid new norms for young } \\
\text { professionals }\end{array}$ \\
\hline 12 & $\begin{array}{l}\text { PAQS, September 27, } \\
2020\end{array}$ & $\begin{array}{l}\text { Status of construction industry and the effects of } \\
\text { COVID- } 19 \text { pandemic }\end{array}$ \\
\hline 13 & IQSSL, Nov 23, 2020 & $\begin{array}{l}\text { Impacts of COVID-19 pandemic on the construction } \\
\text { industry }\end{array}$ \\
\hline 14 & $\begin{array}{l}\text { CPWR-NIOSH-OSHA, } \\
\text { Feb 25, } 2021\end{array}$ & $\begin{array}{l}\text { Protecting construction workers: guidance on } \\
\text { mitigating and preventing the spread of COVID-19 in } \\
\text { the workplace }\end{array}$ \\
\hline 15 & FIDIC, March 2, 2021 & Working together in the new normal \\
\hline
\end{tabular}

\section{FINDINGS AND DISCUSSION}

Table 2 provides the key findings from the webinar content.

Table 2: Key outcomes of webinar discussions

\begin{tabular}{|c|c|c|}
\hline Webinar & Experience/Impact & Alternative/Recommendation \\
\hline 01 & $\begin{array}{l}\text { The labour crisis created by the } \\
\text { COVID-19 pandemic has } \\
\text { increased global unemployment } \\
\text { by almost } 25 \text { million. }\end{array}$ & $\begin{array}{l}\text { Retaining of employment, with deducted } \\
\text { salaries for those who have been made to } \\
\text { stay at home instead of terminating them. }\end{array}$ \\
\hline 02 & $\begin{array}{l}\text { The impact is profoundly severe } \\
\text { in the case of seasonal labour such } \\
\text { as in domestic construction }\end{array}$ & $\begin{array}{l}\text { Due to the nature of the industry, most of the } \\
\text { value additions are done on-site. It would be } \\
\text { ideal to shift to a phased-out approach to } \\
\text { implementation that allows the necessary } \\
\text { time (in the initial phases) to gather first- } \\
\text { hand information about project } \\
\text { characteristics, personnel, and cultural } \\
\text { nuances so that the delivered solution can be } \\
\text { tailored appropriately. }\end{array}$ \\
\hline 03 & $\begin{array}{l}\text { Most informal economy workers } \\
\text { have suffered massive damage to } \\
\text { their capacity to gainfully engage } \\
\text { in some form of income earning. }\end{array}$ & $\begin{array}{l}\text { Companies require a stimulus package as a } \\
\text { short-term measure to ensure wages to } \\
\text { employees for months experiencing no } \\
\text { work. }\end{array}$ \\
\hline 04 & $\begin{array}{l}\text { Working from home is not } \\
\text { possible unless computer } \\
\text { facilities, software, essential hard } \\
\text { copies, soft files, etc. are provided } \\
\text { to the employees. }\end{array}$ & $\begin{array}{l}\text { Arrangements must be made by the } \\
\text { authorities to provide computer facilities, an } \\
\text { uninterrupted network, and other essential } \\
\text { facilities. }\end{array}$ \\
\hline 05 & $\begin{array}{l}\text { The biggest risk seems to be the } \\
\text { continuation of work and } \\
\text { accommodation in line with social } \\
\text { distancing measures. }\end{array}$ & $\begin{array}{l}\text { Working arrangements that reduce onsite } \\
\text { labour congestion is the only option. }\end{array}$ \\
\hline
\end{tabular}




\begin{tabular}{cl}
\hline Webinar & \multicolumn{1}{c}{ Experience/Impact } \\
\hline 06 & $\begin{array}{l}\text { Delays are stemming from a } \\
\text { shortage of craftspeople due to } \\
\text { shelter-in-place restrictions and } \\
\text { delays occasioned by shortages of } \\
\text { government workers available to } \\
\text { perform inspections, issue }\end{array}$ \\
permits, etc \\
In certain jurisdictions, the \\
hardship may allow parties to seek \\
relief based on an exceptional and \\
unpredictable change of \\
circumstances that affects the \\
businesses. \\
Employment protection has been \\
threatened and the loss of income \\
and businesses has threatened the \\
business continuity.
\end{tabular}

09 Computer servers, electronic items, manufacturing tools, testing equipment, and documents idle in offices, sites, and workshops would be damaged or destroyed due to non-maintenance. Also, there can be damages to important data due to overheating, rats, and termite attacks.

10 The construction supply chain is highly impacted, generating project slippage and/or extra costs. Enhanced focus on worker safety and increased cost pressure could accelerate the move to offsite construction methods. The efficiency and controlled environment of factory production can help in leveraging labor costs and in optimizing project schedules.

11 The epidemic and the predictions of environmental changes are bound to reset the status quo.

\section{Alternative/Recommendation}

Online approval methods may be feasible in some cases.

Under many laws, parties must continue to exhaust all reasonably available means to continue performing their obligations, notwithstanding the existence of a force majeure event.

Both the EPF and ETF contributions to be continued during this time - guaranteeing continued social security. Establishments must be allowed to prorate payments according to the number of hours worked by each employee.

Allowing, with some control, at least a technician and the owner must be present to minimize losses. It is better to implement a work schedule on a roaster basis to ensure no damages due to non-maintenance/operation of tools and equipment

It is important to increase competitiveness among the engineering and construction companies in terms of improving the balance between site work, office engineering and factory assembly, etc. Meanwhile taking migratory actions is inevitable. Apps can help keep a track of workers' locations while on the job, in full compliance with privacy regulations, so management can quickly identify potential exposure to the virus.

The industry may need to be more flexible and ready to effect structural changes: We need to commence a dialogue and identify weaknesses and recommend adjustments and/or re-orientation. 


\begin{tabular}{|c|c|c|}
\hline Webinar & Experience/Impact & Alternative/Recommendation \\
\hline 12 & $\begin{array}{l}\text { The unprecedented loss of } \\
\text { productivity among workers } \\
\text { because of distancing } \\
\text { requirements, new safety } \\
\text { protective gear requirements, and } \\
\text { safety procedures-all in addition } \\
\text { to the sick and quarantined } \\
\text { workers who are absent. }\end{array}$ & $\begin{array}{l}\text { In the short term, it's going to be phased out } \\
\text { working arrangements while focusing on } \\
\text { other key areas like improvement of business } \\
\text { processes, eliminating non-value adding } \\
\text { activities, reducing wastage, and driving } \\
\text { workforce with KPIs and training and } \\
\text { development. }\end{array}$ \\
\hline 13 & $\begin{array}{l}\text { Site congestion is inevitable in } \\
\text { building projects than road and } \\
\text { infrastructure projects }\end{array}$ & $\begin{array}{l}\text { It is always important to adhere to } \\
\text { government directives to maintain discipline } \\
\text { at the ground level. Health and safety } \\
\text { protocol is imperative. }\end{array}$ \\
\hline 14 & $\begin{array}{l}\text { Informal traders are particularly } \\
\text { impacted by social distancing } \\
\text { rules and have less access to clean } \\
\text { water and sanitation. Additionally, } \\
\text { with } 60 \% \text { of women across Sri } \\
\text { Lanka employed in the informal } \\
\text { sector, COVID-19 threatens their } \\
\text { economic self-sufficiency from } \\
\text { plying their trade and contributing } \\
\text { to the livelihood of their } \\
\text { household. }\end{array}$ & $\begin{array}{l}\text { Produce necessary policy measures to } \\
\text { enhance social protection coverage and } \\
\text { support mechanisms to protect informal } \\
\text { workers if they lose their livelihoods while } \\
\text { emphasizing the nature of women labour }\end{array}$ \\
\hline 15 & $\begin{array}{l}\text { First, informal workers often work } \\
\text { in economic sectors that carry a } \\
\text { high risk of virus infection. } \\
\text { Among others, waste recyclers, } \\
\text { street vendors and food servers, } \\
\text { construction workers, transport } \\
\text { workers, and domestic workers } \\
\text { are particularly at risk to contract } \\
\text { with COVID-19. }\end{array}$ & $\begin{array}{l}\text { In response, many low and middle-income } \\
\text { countries have started implementing } \\
\text { measures for those in the informal sector and } \\
\text { self-employed workers. Policy responses } \\
\text { include cash transfers as well as the deferral } \\
\text { or reduction of loans, rents, or utility bills for } \\
\text { low-income people for the duration of the } \\
\text { pandemic. }\end{array}$ \\
\hline
\end{tabular}

The fact that the construction as an economic subsector is an informal labour sector has been reiterated in almost every webinar session. Informal workers mean those who work in jobs that are not registered with local authorities or covered by formal working arrangements. This kind of labour does not fall within the tax net, nor eligible for basic social security. During the COVID-19, the informal economy workers faced a lot of issues such as the impact of lockdown and other containment measures. They have no permanent working arrangements or areas, and they faced a challenge to affect by COVID-19 because of the non- arranged work ethic and without the occupational safe workplaces. As Shorter (2020) and Osha (2020) reiterated that governmental restrictions including ban on gatherings, and the contractor's personnel or suppliers being ill or in quarantine, are the situations causing critical delay and inability to meet the project deadlines. All the webinar discussions emphasized this matter. As such, informal economy workers got an economically and socially challenged life. In Sri Lanka, two million workers are employed informally in the construction sector but there is limited research on how they have been affected due to COVID-19. 
The webinar discussions have shed some new thoughts on how to cope with construction labor issues during the pandemic. Retaining of employment with deducted salaries, introducing phased-out approach in sequencing work in hand, offering a stimulus package as a short-term measure of survival, working arrangements that reduce onsite labour congestion work schedule on a roaster basis to ensure no damages due to nonmaintenance/operation of tools and equipment, apps that help keep a track of workers' locations while on the job, eliminating non-value adding activities, reducing wastage and among the temporary measures to ease out the current situation. Policy responses include cash transfers as well as the deferral or reduction of loans, rents, or utility bills for this information labour. One of the common perceptions encountered across all the webinar sessions is the importance of a policy directive specific to construction labour management.

While the construction industry begins to find the new normal, the findings will help in strategizing the way forward in near future and navigate the COVID-19 downturn. In nutshell, while informal employment is universally characterized by a lack of social protection, exposure to occupational health and income risks for informal workers is determined by the specific physical and social environments of their workplaces. Efforts to improve the economic status of informal workers should consider the contexts in which informal work takes place to develop tailored interventions for informal workers.

\section{CONCLUSIONS}

As COVID-19 crisis worsens, its effects on construction industry in Sri Lanka became a key issue and priority. A number of webinar sessions has been organized by professional entities that have some kind of stake in taking care of the wellbeing of the industry. Much attention has been paid to the question of its consequences and the remedial measures available to navigate and ease out the labour crisis. The biggest risk seems to the site congestion and the difficulty to maintain social distancing measures due to the very nature of the industry. Hence, it is high time the professionals and industry regulators together revisit the circumstances and work out a strategy to work 'in harmony with COVID-19' for a less interrupted construction legacy thought-out the country. The findings of this research are introductory to the construction industry stakeholders and policymakers. However, some of the findings can be used to understand the impact of the unforeseen and uncontrolled pandemic on construction-related other industries and other sectors in general. This will help improve the plans to cope with any encountered circumstances.

\section{REFERENCE}

Ayittey, F.K., Ayittey, M.K., Chiwero, N.B., Kamasah, J.S. and Dzuvor, C., 2020. Economic impacts of Wuhan 2019-nCoV on China and the world. Journal of Medical Virology, 92(5), pp. 473-475.

Bailey, J.N., Bouchardie, N. and I. Madalena, I., 2020. COVID-19: The current impact on construction and engineering projects, White \& Case, 2020. [Online] Available from:

https://www.whitecase.com/publications/alert/covid-19-current-impact-construction-engineeringprojects.

Colombo Page, 2020. Sri Lanka's services and industry sectors will feel most of COVID-19 impact, minimal on agriculture sector - ICRA, Colombo Page, 2020. [Online] Available from: http://www.colombopage.com/archive_20A/Apr17_1587098564CH.php.

European Centre for Disease Prevention and Control, 2020. COVID-19 social distancing measures guide second update. Solna Municipality, Sweden, ECDC. [Online] Available from: 
https://www.ecdc.europa.eu/sites/default/files/documents/covid-19-social-distancing-measuresgguide-second-update.pdf

Deloitte, 2020. COVID-19's Impact on the engineering \& construction sector, Deloitte.

Dreze J, Afridi F, Menon P and Vazirali S., 2020. The impact of COVID-19 on informal and migrant workers in India [Webinar]. [Online] Available from: https://www.youtube.com/watch?v=NcVAyxFSt8M

Economy Next, 2020. Sri Lanka listed companies hit by coronavirus, some firms resume works. Economy next.

European International Contractors, 2020. COVID-19 and the global construction business, European International Contractors, 2020. [Online] Available from: https://www.eic-federation.eu/covid-19and-global-construction.

Fernandes, N., 2020. Economic effects of coronavirus outbreak (COVID-19) on the world economy. [Online] Available from: SSRN 3557504.

Financial Times, 2020. Real-time data show virus hit to global economic activity, Financial Times, [Online] Available from: https://www.ft.com/content/d184fa0a-6904-11ea-800d-da70cff6e4d3

Food and Agriculture Organization of the united Nation, 2020, Impact of COVID-19 on informal workers. [Webinar]. [Online]. Available at: http://www.fao.org/3/ca8560en/CA8560EN.pdf

Goodman, J., 6 Ways the Coronavirus Outbreak will Affect Construction. Construction Dive. [Online] Available from: https://www.constructiondive.com/news/6-ways-the-coronavirus-outbreak-willaffect-construction/574042/

Harari, Y.N., 2020. The world after coronavirus. Financial Times, 20(03), p. 2020.

Helm, D., 2020. The environmental impacts of the coronavirus. Environmental and Resource Economics, 76, pp. 21-38.

International Training Center, 2020. Global online forum on impact of the COVID-19 crisis on the informal economy: main findings and ways forward from a south-south perspective. [Webinar]. [Online]. (Webinar). Available from: https://www.itcilo.org/courses/global-online-forum-impact-covid-19crisis-informal-economy-main-findings-and-ways-forward

Ivanov, D., 2020. Predicting the impacts of epidemic outbreaks on global supply chains: A simulationbased analysis on the coronavirus outbreak (COVID-19/SARS-CoV-2) case. Transportation Research Part E: Logistics and Transportation Review, 136, p. 101922.

Jayalath, C., 2020, Resumption of construction in harmony with COVID-19 is the solution, Lanka Web, 01 May, 2020. [Online] Available from: http://www.lankaweb.com/news/items/2020/05/01/resumptionof-construction-in-harmony-with-covid-19-is-the-solution/

Jayalath, C. and Somarathna G., 2020. Revisiting the argument of force majeure in the context of construction during COVID-19, National Engineering Research Symposium, NERS 2020, Sri Lanka

KPMG. 2020. Impact of COVID-19 on the Sri Lankan economy. KPMG.

Kulathunga, H., 2020. Issues affecting construction industry due COVID-19. Colombo, Sunday Observer. [Online] Available from: http://www.sundayobserver.lk/2020/04/12/news-features/issues-affectingconstruction-industry-due-covid-19

Lee, S., Jomo, K.S., Sen, K., Pirates, I. and Barbosa, R., 2020. Implications of the COVID-19 crisis for labour and employment in India: Impact, strategies and perspectives [Webinar]. [Online]. Available from: https://www.wiego.org/events/implications-covid-19-crisis-labour-and-employment-indiaimpact-strategies-and-perspectives

Lee, S., Schaller, B., Yoon, C., Hadley, T., Behrendt, C., Nunes, J.P., Delfosse, S., Evelyn, A. and Morales, L.R., 2020. COVID-19: Social protection for recovery [Webinar]. [Online]. Available from: https://www.ilo.org/emppolicy/events/WCMS_756738/lang--en/index.htm

Archibald, M.M., Ambagtsheer, R.C., Casey, M.G. and Lawless, M., 2019. Using zoom videoconferencing for qualitative data collection: perceptions and experiences of researchers and participants. International Journal of Qualitative Methods, 18, p. 1609406919874596.

Marrero, L., Kotor, E.Y., Galdo, L., Abunda, M.A., Gasparrini, L., Witbooi, M. and Koning, M., .2020. International Domestic Workers' Day [Online] Available from: https://www.ilo.org/global/topics/domestic workers/events-and-training/WCMS_745956/lang-en/index.htm 
Ministry of Health \& Indigenous Medical Services, 2020. Guidance for workplace preparedness for COVID-19, Sri Lanka: Ministry of Health \& Indigenous Medical Services

World Health Organization, 2020. Naming the coronavirus disease (COVID-19) and the virus that causes it. World Health Organization. [Online] Available from: https://www.who.int/emergencies/diseases/novel-coronavirus-2019/technical-guidance/naming-thecoronavirus-disease-(covid-2019)-and-the-virus-that-causes-it

Nicole, M., Alsafi., Z., Sohrabi, C., Kerwan, A., Al-Jabir, A., Losifidis, C., Agha, M. and Agha, R., 2020. The socio-economic implications of the coronavirus and covid-19 pandemic: A review. International Journal of Surgery, 78, pp. 185-193.

OSHA, 2020. COVID-19 Guidance for the construction workforce, 2020. OSHA.

PWC, 2020. COVID-19 Outbreak, impact on Sri Lanka and recommendations. Price Waterhouse Coopers (Private) Limited.

PWC, 2020. COVID-19: What it means for engineering and construction. Price Waterhouse Coopers (Private) Limited.

Robertson, D., Secomb, M. and Elliott, E., COVID-19: Managing force majeure risk in a construction project supply chain, White \& Case. [Online] Available from: https://www.whitecase.com/publications/alert/covid-19-managing-force-majeure-risk-constructionproject-supply-chain.

Shorter, C., Nairac, M., Burianski, D., Kondev, and Achkar, Y.E., How should the impact of the COVID19 outbreak be managed on projects under FIDIC and NEC? 2020. [Online] Available from: https://www.whitecase.com/publications/alert/how-should-impact-covid-19-outbreak-be-managedprojects-under-fidic-and-nec.

Staermose, T., Mapa, S., Cuk, V., Behrendt, C. and Dierckxsens, M., 2020. COVID-19 and the world of work: Implications for people with disabilities [Webinar]. [Online]. Available from: https://www.ilo.org/global/topics/disability-and-work/WCMS_747872/lang--en/index.htm

Tiong, W.N. and Sim, A.F.S.F., (2020). Web-based seminar - New source of qualitative data: Data collection during the pandemic of COVID-19. Journal of Management, 3(6), 50-64.

Turrini M., Hakim I., Rahman H., and Hudson S., COVID-19: Considerations for future construction contracts, White \& Case, 2020. [Online] Available from: https://www.whitecase.com/publications/alert/covid-19-considerations-future-construction-contracts.

Wijerathne, N., 2020. Coronavirus impedes Sri Lanka's construction projects, Global Construction Review, CIOB.

William, 2020. The impact of COVID-19 on the Sri Lankan construction industry \& the Sri Lankan economy [Online] Available from: https://medium.com/@avankawilliam. 